\title{
横井時敬の都市農村計画思想とハワード「田園都市論」
}

\section{Tokiyoshi Yokoi's Vision on Town and Country Planning and Garden City Theory of Ebenezer Howard}

\section{村上暁信*}

Akinobu MURAKAMI

\begin{abstract}
摘要 : 近代都市計画の始点であるとされるエベネザー・ハワードの田園都市論を農学の立場から最初 に日本に紹介したのは農学者横井時敬であった。横井は, 田園都市論は都市に田舎の趣味を持ち込ん だものであるが，自らは農村本位の立場にたつとした。そして明治 42 年に自身の計画思想を小説模 範町村にまとめた。横井は, ハワード「田園都市論」とはまったく異なるものであるとしているが, 両者を詳細に比較することにより，その実現の方法は異なるものの，地域環境と共存したかたちで都 市と農村を融合させ, 自足的な協同社会を目指していたという点では共通点の多い提案であったこと が考察された。
\end{abstract}

\section{1.はじめに}

近代都市計画の原点は 19 世紀末にイギリス人のエベネザー・ 八ワードが提案した田園都市論にあるとされている。ハワードは その中で, 都市と農村を融合させることを提案している。しかし ハワード「田園都市論」はその後, 大都市のみを対象として議論 されることが多く，また「都市と農村の融合」という考え方はそ の後の都市計画運動の中では取り上げられることはなかった。

近年の我が国においては情報化の発達などにより，今後都市機 能が急速に地方へ分散していくことが予想される。そしてそれに 伴い, 都市と農村の新たな関係の構築やその一体的整備手法の提 案が求められている。すなわち, 本来の都市と農村の融合という 意味での田園都市論の展開，それも大都市を対象としたものでは なく, 農村を対象とした田園都市論の展開が現在求められている のである。

このような新たな展開を考えていくためには，それが単に新し い計画として提案されるのではなくこれれでの田園都市論の日 本における影響やその発展過程の再検討を踏まえたものである必 要がある。

そのために本研究においては, 日本で最初に農学の立場から八 ワード「田園都市論」を紹介した横井時敬を取り上げ，特に横井 自身が都市と農村の関係についてその思想を記したとしている小 説模範町村を中心に, 横井の考えの特徴やその意義について考察 することを目的とした。

横井時敬に関しては，「横井博士全集」という全 10 巻からなる 膨大な著作集が発刊されている。また横井の人物や学問に関して あ既に多くの研究があり，小説模範町村についてもいくつかの研 究で取り上げられている(122334)。しかし，横井の都市農村観につい てハワード「田園都市論」と比較し, 詳細に考察したものはほと んどみられない。そこで本研究においては, 横井の都市農村観を, ハワードの都市農村観と比較することでより明確にすることを目 指した。

\section{2. ハワード「田園都市論」}

18 世紀にイギリスで起こった産業革命はその後急速に広まり， 社会生活の様々な面で重要な問題を派生させた。特に農村から都 市への人口流入に伴う都市住環境の劣墨化と農村の衰退は深刻な 問題となっていた。そのような状況の中，ハワードは 1898 年の
著書, 'Tomorrow : A Peaceful Path to Real Reform' 5) (1902 年に 'Garden Cities of To-Morrow' 6)「明日の田園 都市」之改題されて再版）において，都市農村問題を解決するた めには双方が互いに補い合わなくてはならないとし，都市と農村 を融合させた新たな形態である田園都市（図－2）の建設を提案 した。

田園都市の大きさは約 6,000 エーカーとされ，中央部の 1,000 エーカーが市街地として計画されている。市街地中央には大公園 が設置され，さらにその中心には公共建築物が配置されている。 市街地の外周には鉄道が環状に走り, その外側は製造丁場, 病院, 学校等の敷地之農業用地とされ, 人口は市街地 30,000 人, 農業 用地 2,000 人の合計 32,000 人とされている。また, 田園都市に おいては協同の原則に基づいて，様々な組合やサークルがつくら れ，社会生活を豊かにするとしている。

'Tomorrow : A Peaceful Path to Real Reform' 出版翌 年の 1899 年には多くの人々の賛同を得て, 田園都市協会が創設 された。そしてこの協会により，1903 年には，ロンドンの中心 から北へ 35 マイル離れた場所に 4,500 エーカーの土地が購入さ

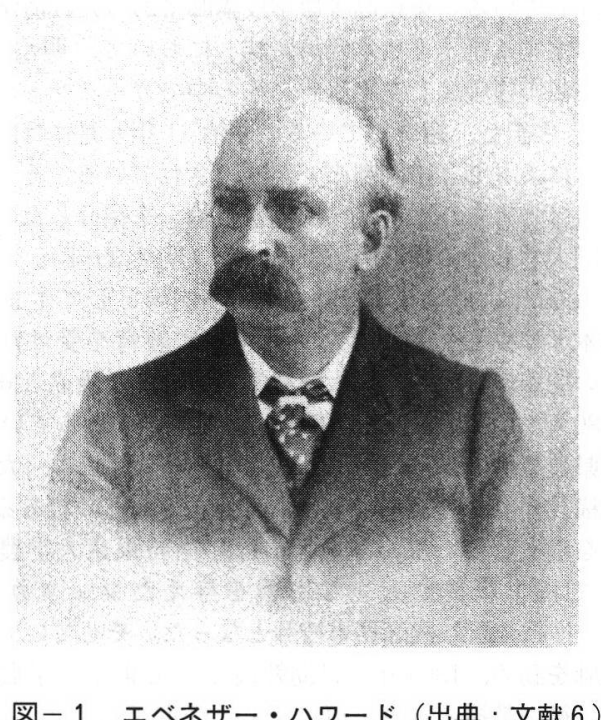

図ー1 エベネザー・ハワード（出典 : 文献 6) 


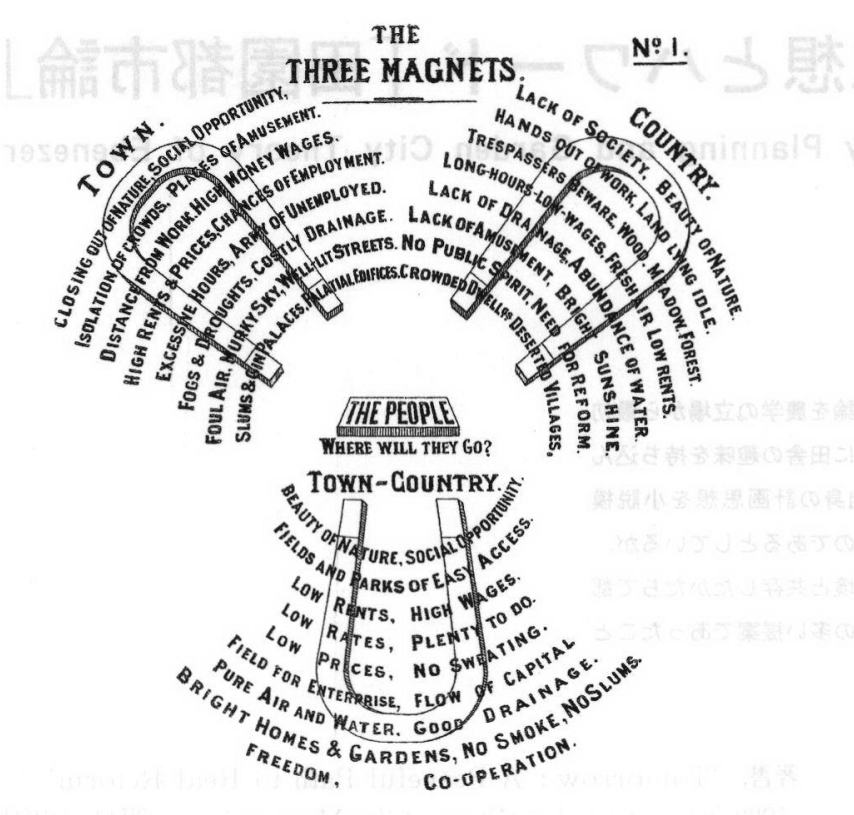

図ー2 ハワードのダイアグラム（出典 : 文献 6 ))

れ，最初の田園都市レッチワースの建設が開始された。

イギリスで最初の都市計画法である, 1909 年の都市計画及び 住宅等法策定の際には立法の論拠としてレッチワースの建設が多 く参照された ${ }^{7}$ 。また 1940 年の Barlow 委員会の報告 ${ }^{8)}$ におい ても田園都市論の理念が紹介されるなど, ハワード「田園都市論」 はイギリス都市計画の発展に様々に影響を与えてきた。またイギ リス以外の国においても多大な影響を与えたことか知られている。

\section{3. 横井時敬の小説模範町村}

日本においては, ハワード「田園都市論」は 1907 年頃から様々 なかたちで紹介されるようになった。東京日日新聞社経済部長の 三宅磐は，明治 40 年 3 月から同紙に G. Montagu. Harris の 著書, ‘The Garden City Movement' の要旨を「花園都市」 として紹介している。東京高等農学校講師であった経済学者河上 肇は自ら主宰する雑誌「日本経済新誌」において, 明治 41 年 2 月に「花園都市建設論」を発表し，その中でガーデン・シティを 「花園都市」と訳し, 紹介している。明治 41 年 5 月には内務省地 方局の有志によって「田園都市」が発行されている。そして農学 の立場からはじめてハワード「田園都市論」を紹介したのが，当 時東京帝国大学教授の横井時敬であった (明治 39 年)。

横井は 1860 年に熊本県の坪井に士族の四男として生まれ，幼 い時は熊本洋学校でアメリカ人シェーンに教育を受けた。1 878 年に東京の駒場農学校 (東京大学農学部の前身) 設立と同時に入 学し，1880 年に卒業した後，福岡県立農学校に勤めている。そ して福岡県農事試験場に代わるとともにその場長となった。この 時期に，横井の多くの業績の中であ特筆すべきあのである「塩水 選種法」を創案している。1 889 年には, 当時東京大学農科大学 教師として日本農業に大きな影響を与えたフェスカ（Max Fesca）の推萀により農商務省技師となった。そしていくつかの 学校で講師を勤为, 1894 年には助教授として東京大学農科大学 に移った。後に教授となり，東京大学には定年引退の 1922 年ま でとどまった。当初は栽培論などの技術論的講義を担当していた が, その後は経済論的講義や農政的講義担当している。また横井
は東京農学校には創立当初から深く関わり，1897 年の大日本農 会附属東京農学校以来, 教頭・校長を務め, 東京農業大学之なっ てからは初代学長として生涯務めた。

横井が最初に田園都市論に言及したのは, 読売新聞に連載して いた「都会と田舎」という評論の最終回においてであり（明治 39 年),「田舎と都会との調和」9) と題したなかで花園市 (ガルデン シチー）に論及している。そこでは,「花園市！これが設計は 即ち花園市の理想であるが, 之れが理想を実行せんと欲する英国 は，其の必要条件として，余は信ずる，其の農業の回復を図らざ るを得ないのであるを。よしている。横井は, 農業農村の振興 なくして田園都市論の目指す理想社会の実現は不可能であるとし て, 自身の立場がハワード「田園都市論」と違うことを明確に示 しているといえる。そして横井が自身の理想とする考えを記し $た^{10)}$ のが, 明治 40 年に発刊された小説模範町村 ${ }^{11)}$ であった。

横井は幼少の頃より小説好きであったが，自ら小説を書いたこ とはなく, 模範町村を書くには大変苦労し, 小説家の徳田秋声の 助けを得てようやくこの小説を完成させた。

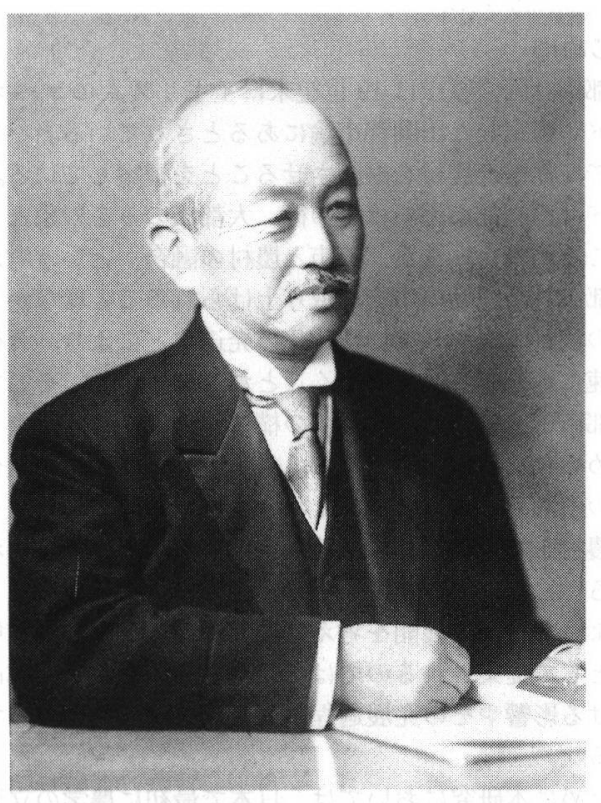

図 - 3 横井時敬

(東京大学大学院農学生命科学研究科 農業経営学研究室所蔵)

小説の舞台となる村は豊坂村といい，30 年前は戸数 500 戸，水 田 1,000 町歩, 畑 500 町歩, 山林が 5,000 町歩の広さであった。 村は産物も少なく，山は秃げ山同然であり，青年は都会へと出て いくために衰退しつつある村であった。

この村の村長に, 村出身で農科大学を出た稲野という人物が就 任し，30 年をかけて村をつくりかえるのである。小説は, 久し ぶりに村へ州ってきた医学士小田春雄の見聞というかたちで展開 し, 改善された村の特徵が紹介される。村は稲野村長の努力によ り, 土地改良が行われて水田の反収も増し, 園芸や畜産む発展し ている。各人は菜園を所有し, それを楽しみとするとともに収入 の足しにしている。村での農業は部分的に協同して一括的になさ れることで効率が上げられており，農業教育の制度も整っている。 農業試験場や穀物倉庫を協同して設置することで農業振興にも高 く貢献している。また, 道路や橋, 上水道, 水力発電所, 最新の 設備を持った総合病院，学校，公園などが整備されている。村の 文化的生活の披点としては公会堂がつくられ，そこにはレストラ 
ンや風呂，図書室，玉突きができる遊技場などがある。また公会 堂では, 芝居やコンサートが開かれている。このように豊坂村で は, 作業の協同化と社会施設や文化施設の整備により, 文化生活, 社会生活において都会と同じ生活ができるようになっている。そ してその結果, 青年が都会へ出ていくこともなくなり，また都市 に依存することもなく自立した村となっている。

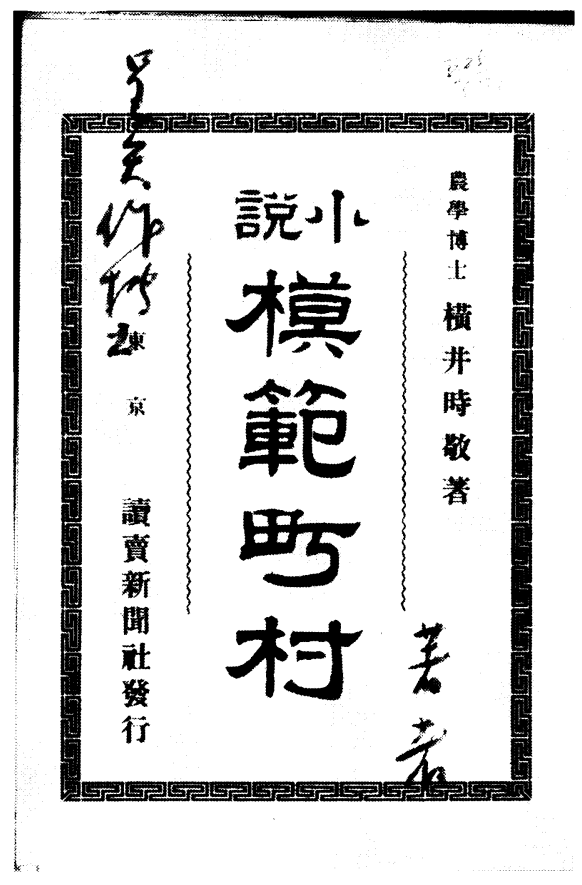

図-4 小説模範町村の表紙（出典 : 文献 11）

あう一つ豊坂村において特徵的なのは, その農業形態である。 かつては村民が勝手に木を切ったり薪を作ったりしていたために, 山林は秃げ山となっていたが，これを村で管理することにより， 植林之伐採の均衡を図っている。その結果，山林の持続的な利用 が可能となっている。さらにその管理に関しては，草の根に充分 な養分を貯えられるように余地を見極めて鎌止めの期を一定にす ることや，5年ごとに火を入れて，刈り株の更新を図ることで余 分な有機物の集積を防ぐことなどを，学理に基づいて具体的に定 めている。また肥料に関しては，草を刈り，腐敗させて堆肥を作 るとしている。これらは，現代的にみれば，地域環境と共存した かたちでの農業を実践しているといえる。

\section{4. 横井時敬の小説模範町村とハワード「田園都市論」}

横井の考えがハワード「田園都市論」と明確に違うということ を，横井自身が当初から述べていることは先にも触れたが，明治 42 年 1 月の論文「模範農村」においてはさらにこの点に関して 詳しく記述している ${ }^{12)}$ 。横井はその中で, 都会と田舎との関係に 関して田舎から大量に都会へ人口が流出していっている現状を極 めて重大な問題であるとした上で，その解決策として次の 3 つを 挙げている。

1. 都会を田舎化せんとする方案 これは「ハワルト氏」の説 で，一都会の人口を三万人に制限し，又各戸に幾らかの田園を付 しなどして, 出来得る丈け都会を田舎的ならしめんとする都会救 済策である。

2. 都会の労働者を住居せしむる方案 此説は労働者を田舎に 住ませ, 汽車や電車等の交通機関を整頓し, 且つ出来得る丈此等 の運貨を廉にし, 毎日都会に通って労働せしむるといふ説である
が，実験上余り効果を得ぬといふことである。

3. 余自身の説 余が主張する方案は「ハワルト氏」の都会に 田舎趣味を加味せんとする都会本位主義の正反対にて, 田舎に都 会趣味を輸入し，現今の無趣味殺風景なる田舎を有趣味にし，農 村の青年を田舎に引き止めんとする一種の田舎振興策にして, 田 舎本位主義である。

また別の論文においては，「田園都市の創案者は，都会に田舎 の趣味を加へんと欲するが如く，余は田舎に都会の趣味を帯ばし め, 以て都市的田園となさんと欲するものである，余が著したる 小説模範町村は，やがて都市的田園を組立てたるものである，余 は田園都市の成功を疑ふと同時に，都市的田園の必ずしも成功せ ざるにあらざるを信ぜんと欲するものである，否，之を以て急務

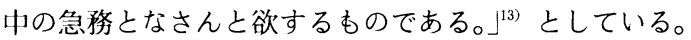

これらにおいて横井は，ハワード「田園都市論」を「都会を田 舎化せんとする方案」としており，この点において横井の考えと 異なるとしている。しかし八ワードは単に, 都市に農村の趣味を 持ち込もうとしたのではなかった。

ハワードは田園都市建設が郊外型住宅地建設と混同されること に対して,「郊外型住宅地の建設は農村の衰退という問題に対し てなんの取り組みむしておらず，この点において田園都市の建設 とはまったく異なるものである。 $1^{14)}$ とている。このことから むハワードは単に都市だけを考えていたのではなく, 都市農村融 合の実現を目指していたといえる。

またハワードは，田園都市論を形成する際には，ウェイクフィー ルドとマーシャルの植民地論に大きな影響を受けたとしている。 実際に田園都市論においては，住民が增えるに従って土地の価格 が上がり，その利益で都市を整備していくことを計画している。 つまり都市と農村の融合を実現させる手法として，ハワードは農 村に，都市の施設とともに都市住民も持ち込むことで新しい社会 をつくりだそうとしたのである。この点において, 横井が現存す る農村に都市の施設のみを持ち込み, 農村の再生・自立を図ろう としたのと異なるといえる。

一方で，横井と八ワードが目指していた社会の中身については 共通点が多い。どちらの提案においても，住民は都市的施設とと もに農村の美しい景観を楽しむことができるとしているし，住民 が協同することで多くの無駄を省き効率的に社会生活を営むとい う点も共通している。

特に公会堂の設置や，組合の設立，教育の充実などに関しては 両者の提案は非常に似たものとなっている。しかし横井はこれら の問題に関して，ハワード「田園都市論」に言及するよりも以前 から発言している。1901 年の「田舎に於ける都会熱並に之が対 策」 ${ }^{15)}$ 以来横井は様々な場において, 都市的娛楽の農村への導入 や協同的組織の設立，農村における教育の充実を訴えてい $3^{(6) 17) 181919}$ 。また小説に描かれているこれらのことは，ハワードが 田園都市論の中で提案したものよりも詳しいものとなっている。 以上の点加，小説模範町村に出てくる村と田園都市の様子は似 てはいるが，それはハワードの影響を受けたものではなく，横井 独自の思想を表したものであったと考えられる。

またハワードは，都市に関する記述が多いためにこれまであま り触れられることはなかったが，農村に関しても非常に重要な提 案をしている。農村は人々を喜ばせるとしたり，余暇の楽しみを 増大させると述べるなど，食糧生産の場としての機能の他に，レ クリエーション的な機能やアメニティ機能む持たせているのであ る。さらに田園都市は自足可能なものであることを強調し，水路 をはりめぐらして雨水を最大限活用すること，大気を污染しない ように電力を水力発電や風力発電でまかなうこと, 都市内で生じ る廃棄物は農地で肥料として再利用すること, 田園都市内で食糧 を自給することなどを提案している。これらは現代的にみれば, 
一種の循環系構築の提案であるといえる。ハワード直筆のノー ${ }^{200}$ には, 水力発電や風力発電に関する記事, 下水処理に関する 記事，電気機関車に関する記事など，環境に負荷をかけない技術 に関する記事の切り拔きが数多く残されている。循環系を構築す るためにこれらの技術を導入するつもりであったと考えられる。 つまりハワードは, 農地を多機能を持つものとして位置づけた うえで，一種の循環系を備えたものとして都市と農村の一体的整 備を目指していたといえる。このような点も横井の提案と非常に 似ているといえる。しかし， ハワードの提案が概念的であるのに 比へ，横井は農業の形態について細かな点まで触れている。これ は，ハワードは新都市建設に重点を置いた中で理想的社会を論じ, 一方横井は農学者の立場加農村の再生・自立という点を中心に 論じたという，それぞれの描き方の違いによるものと考えられる。

\section{5.まとめ}

本研究から得られた知見を以下にまとめる。

横井時敬は, ハワード「田園都市論」を「都会を田舎化せんと する方案」として，この点において横井の考えと異なるとしてい るが，ハワードも単に都市に農村を導入しようとしただけではな く, 都市と農村の融合を目指していたのであり, 両者が実現しよ
うとした社会像は実際には非常に近いものであった。

しかし，その実現へ向けての手法において，ハワードは都市住 民も含めて，都市的施設を農村に導入しようとしたのに対し，横 井は現存する農村に都市的施設のみを導入しようとしたのであり， この点において違いがあったといえる。

また両者ともに，地域環境と共存したかたちでの自立社会を目 指しており，このような考えは今後の農村計画の課題として近年 注目されている考え方に非常に近いものであるといえ，評価でき る。特に横井の模範町村に詳細に描かれた農業形態は今日におい ても古さを感じさせない先駆的な提案であると評価できる。

謝辞 : 本研究を進めるにあたって, 東京大学大学院農学生命科 学研究科の井手久登教授, 東京大学アジア生物資源環境研究セン 夕ーの武内和彦教授に御教示を睗りました。また東京農業大学で は，特别な御配虑により同大学所蔵の貴重な資料を閲覧させて頂 きました。さらに, 東京大学大学院農学生命科学研究科農業経営 学研究室の八木宏典教授の御好意により同研究室所蔵の横井時敬 の肖像写真を複写させて頂きました。この場を借りて御礼申し上 げます。

\section{参考文献}

1 ）金沢夏樹・松田藤四郎編著（1996）： 稲のことは稲にきけ 近代農学の始祖 横井時敬：家の光協会, 369pp.

2 ）渡辺俊一（1993）：「都市計画」の誕 生一国際比較からみた日本近代都市計 画一: 柏書房, 52-53.

3 ) 東畑精一 (1984): わが師わが友わが 学問 : 柏書房, 83-89.

4 ) 桜井武雄 (1979): 田園都市論に関す る解説 : 茨城県農業資料田園都市編 : 茨城県農業史研究会, 7-14.

5 ) Howard, Ebenezer (1898): Tomorrow : A Peaceful Path to Real Reform : Swan Sonnenschein, London, 176pp.

6) Howard,Ebenezer (1902) : Garden Cities of To-Morrow : Swan Sonnenschein, London, 191pp.

7 ) パードム, C. B. (1977)：レッチワー
ス : 計画評論 $14,132 \mathrm{pp}$.

8 ) Royal commission on the distribution of the industrial population (1940): Barlow report: H. M. stationery office, London.

9 ) 横井時敬(1906)：田舎と都会との調和 : 横井博士全集第 4 巻（大日本農会編. 横井全集刊行会. 1929），594-597.

10）横井時敬（1909）：模範農村：横井博 士全集第 7 巻, 90 .

11）横井時敬 (1907)：模範町村：読売新 聞社, $172 \mathrm{pp}$.

12）横井時敬（1909）：模範農村：横井博 士全集第 7 巻, 86-90.

13）横井時敬：田園都市と都市的田園：横 井博土全集第 5 巻, 181

14) Howard, Ebenezer: Hertfordshire County Archive : E/Ho : Folio 3.

15）横井時敬（1901）：田舎に於ける都会 熱並に之が対策：大日本農会報 232，
1-9.

16）横井時敬（1908）：農村に適する娛楽 的遊戯方法: 大日本農会報 $322,32-$ 35.

17）横井時敬（1909）：田園都市之都市的 田園 : 大日本農会報 331, 1-5

18）横井時敬（1910）：農村問題に関する 雑感: 大日本農会報 350, 1-7.

19）横井時敬（1903）：今日の我農村：中 央農事報告書 $36,8-14$ 。

20) Howard, Ebenezer : (Printed book) Tomorrow : A Peaceful Path to Real Reform (interleaved and with author's alterations in preparation for republication under title of "Garden Cities of T o-morrow."): (Swan Sonnensche in):Hertfordshire County Archive: $\mathrm{E} / \mathrm{Ho}$ : Folio 4

Summary : Ebenezer Howard, who wrote “Tomorrow: A Peaceful Path to Real Reform” in 1898, played an important role in development of town planning. Tokiyoshi Yokoi, who introduced the garden city theory of Howard to Japan from the view of country planning, thought the garden city theory as just country-like town planning. And then he published a novel titled "Mohan Chouson (Ideal Town and Country)", in which he showed his vision on country planning. However, when compared the garden city theory with Yokoi's vision on country planning, the following findings were obtained. Although their approaches were different from each other, they both intended to develop self-contained and sustainable community. 